\title{
Effect of Bio-Regulators on Improvement in Chemical Traits, Strorage Life and Organoleptic Quality of Ratol Mango
}

\author{
Dharmendra Kumar Gautam ${ }^{1}$, Anil Kumar ${ }^{2 *}$, Virendra Kumar ${ }^{3}$, \\ Mahesh Kumar ${ }^{1}$ and Satya Prakash ${ }^{1}$
}

${ }^{1}$ Department of Horticulture, SVPUAT, Meerut-250110 (U.P.), India

${ }^{2}$ Department of Horticulture, SHUATS, Allahabad-211007 (U.P.), India

${ }^{3}$ Department of Pathology, CSAUAT, Kanpur-208002 (U.P.), India

*Corresponding author

\begin{abstract}
A B S T R A C T
The field experiment was conducted at Horticultural Research Centre (HRC), old campus of Sardar Vallabhbhai Patel University of Agriculture and Technology, Meerut, Uttar Pradesh, during 2011-12 and 2012-13. The study was concentrated on improvement in

\section{Keywords}

Biological regulators, Mango, Quality, Storage life, Chemical attributes, Ratol

Article Info

Accepted: 20 July 2018 Available Online: 10 August 2018 chemical traits, storage life and organoleptic quality of Ratol mango through application of biological regulators. Three biological regulators viz. Daminozide (50 ppm and $100 \mathrm{ppm}$ ), NAA (25 ppm and $50 \mathrm{ppm})$ and $\mathrm{GA}_{3}(25 \mathrm{ppm} 50 \mathrm{ppm})$ were used. Water was used as control. TSS was found to be highest with 50 ppm NAA $\left(24.44{ }^{\circ}\right.$ Brix $)$ while control fruits had the minimum TSS (18.22 ${ }^{\circ}$ Brix). A $29.86 \%$ increase in TSS over control was registered in the present study with $50 \mathrm{ppm}$ NAA over control. Titratable acidity was found to be maximum with 50 ppm $\mathrm{GA}_{3}(0.17$ and $0.18 \%)$, while control fruits had registered minimum titratable acidity $(0.09$ and $0.10 \%)$ during both the years of investigation, respectively. Maximum increase of $100 \%$ increase in titratable acidity with 50 ppm $\mathrm{GA}_{3}$ when compared with control. 50 ppm GA $3(23.39 \%)$ had resulted in maximum increase in total. Storage life was also found to be maximum (12.16 days) with $50 \mathrm{ppm} \mathrm{GA}_{3}$. Lowest decay loss of fruits was recorded with $50 \mathrm{ppm} \mathrm{GA}_{3}(7.76 \%$ and 8.30 $\%$ ) during both the years of investigation, respectively. Maximum organoleptic score was obtained with $50 \mathrm{ppm} \mathrm{GA}_{3}$ (4.50 score value).
\end{abstract}

\section{Introduction}

Mango (Mangifera indica L.) is one of the popular fruits in the world due to its attractive colour, delicious taste and excellent nutritional properties. Known for its sweet fragrance and flavour, the mango has delighted the sense for more than 4000 years. A celebrated fruit mango now produced in most of the tropical parts of the globe.
Mango is greatly relisted for its succulence exotic flavour and delicious taste in most of the countries of world. It is an important nutritious fruit as it is a good source of $\beta$ carotene (a potent precursor of Vitamin-A) and Vitamin-B and Vitamin-C.

Though mango is a tropical fruit, it grows equally well under sub-tropical conditions. In India, this premium fruit is having a great 
cultural, socio-economic and religious significance since ancient time. In northern India mango flowers from February to March and the period of full bloom may be some time during March. Bloom period in eastern India is earlier than in the north. In north India the duration of flowering in mango is for about 20 to 25 days (Singh, 1958). Ratol is one of the finest cultivars which possess most of these cited qualities. This cultivar originated in small village of RATOL in the district Baghpat (U.P.). Pakistan has monopoly in the export of this important mango cultivar and the country earns handsome foreign exchange by exporting Ratol to European and gulf countries. The carrot flavour of the fruit is the unique characteristics of this delicious cultivar. However, small fruit size, bigger stone, higher stone pulp ratio and poor shelf life are the most limiting factors in its successful cultivation.

The plant bio-regulators or hormones are the organic chemical compounds, which modify or regulate physiological processes in an appreciable measure in the plant when used in small concentration. They are readily absorbed and move rapidly through the tissues, when applied to different plant parts. These chemicals are specific in their action. It would be therefore worthwhile to improve the quality of fruit crops by foliar application of plant growth regulators. The use of plant growth regulators has assumed an integral part of modern crop husbandry for increasing production and productivity of quality fruits. Thus the use of plant growth regulators has resulted in some outstanding achievements in several fruit crops with respect to fruit quality. Use of bio-regulators is a new approach of manipulating plant biological activities for enhancing quality and nutritive value in fruit crops. Foliar sprays of growth regulators (NAA and GA3) could be used as one of these horticultural practices that reduce fruit drop enhance yield and fruit quality of mangoes (Anila and Radha, 2003). Moreover, NAA application reduced flowers drop, and gave high flowers retention and increased yield as well as improved fruit quality of mango (Vejendla et al., 2008). Furthermore, foliar spray of NAA and GA3 enhanced yield and fruit quality as well as reduced fruit drop of mango trees (Nkansah et al., 2012).

Despite of its excellent taste and flavour, due importance has not been given to this premium cultivar in the country. The complete knowledge of bio-chemical attributes of this cultivar is lacking which is the most important pre-requisite for successful orcharding. Scientific research work has not been made to study the bio-chemical attributes of the premium cultivar in the country. Therefore, keeping in mind the role and action of these bio-regulators in fruit crops and considering the importance of this cultivar it was realised to study the effect of bio-regulators on chemical traits and organoleptic quality of Ratol mango.

\section{Materials and Methods}

The field experiment was conducted at Horticultural Research Centre (HRC), old campus and also in the laboratory of Department of Horticulture of Sardar Vallabhbhai Patel university of Agriculture \& Technology, Meerut (U.P.) 2011-12 and 201213.Three biological regulators viz. Daminozide (50 ppm and 100 ppm), NAA (25 ppm and $50 \mathrm{ppm}$ ) andGA 3 (25 ppm $50 \mathrm{ppm}$ ) were used as treatment. Water was used as control treatment. The experiment was conducted in RBD (Randomized Block design) with 7 treatments replicated thrice. The experiment was carried out in the same orchard during both the years of investigation. During thestudy, observations were taken for Total soluble solids (TSS), titratable acidity, total sugars, storage life, decay loss per cent 
and organoleptic quality. The data were analyzed by using the 'Analysis of Variance Technique' as per the procedures described by Panse and Sukhatme, 1985. The treatment means were compared at $5 \%$ level of significance.

\section{Results and Discussion}

\section{Chemical attributes}

\section{Total soluble solids}

The total soluble solids (TSS) content in Ratol mango was significantly affected by the foliar application of bio-regulators. Data presented in Table 1 revealed that level of total soluble solids influenced by various treatments which varied from $18.82{ }^{\circ}$ Brix (control) to 24.44 ${ }^{\circ}$ Brix (50 ppm NAA) during both the years of study. The pooled value of TSS was also found affected due to foliar application of plant bio-regulators in the same way as was observed during 2011-12 and 2012-13. The pooled data revealed that TSS was found to be highest with 50 ppm NAA (24.44 ${ }^{\circ}$ Brix) while control fruits had the minimum TSS (18.22 ${ }^{\circ}$ Brix). A $29.86 \%$ increase in TSS over control was registered in the present study with 50 ppm NAA which was found to be at par with 25 ppm NAA (26.04\%) increase in TSS over control. A maximum improvement of $5.62{ }^{\circ}$ Brix in total soluble solids was observed with 50 ppm NAA followed by 4.90 ${ }^{\circ}$ Brix increase in TSS with 25 ppm NAA when compared with control.

These results are similar to the findings of many mango researchers who observed higher level of TSS in mango fruits with the application of NAA (Osama et al., 2015 and Bairangi, 2013). Improvement in TSS content in mango fruit could be attributed to higher solutes as a result of enhanced mobilization of carbohydrates in these treatments. Present findings are further supported by the fact that activity of sucrose phosphate synthase, a key enzyme regulating the pool size of sucrose in the leaf, had been shown to be stimulated by foliar application of auxin and promotes phloem loading (Baker, 1985).

\section{Titrable acidity}

The perusal of data presented in Table 2 indicated the significant response of bioregulators on titratable acidity in Ratol mango. The titratable acidity as influenced by different treatments ranged from $0.09 \%$ (control) to $0.18 \%$ (50 $\mathrm{ppm}^{\mathrm{GA}} 3$ ). Among bio-regulators applied, titratable acidity was found to be maximum with 50 ppm $\mathrm{GA}_{3}(0.17$ and $0.18 \%)$ followed by $25 \mathrm{ppm} \mathrm{GA}_{3}(0.15$ and $0.17 \%$ ). The control fruits had registered minimum titratable acidity (0.09 and $0.10 \%)$ during both the years of investigation, respectively. Data also showed a maximum increase of $100 \%$ increase in titratable acidity with $50 \mathrm{ppm} \mathrm{GA}_{3}$ when compared with control. Further, a maximum increase of 100 $\%$ titratable acidity in Ratol mango over control was registered with 50 ppm $\mathrm{GA}_{3}$ followed by $77.78 \%$ increase titratable acidity over control with 25 ppm GA 3 .

The improvement in acidity in fruits due to foliar application of growth promoters could have been possible due to transformation of organic acids into sugars at the time of ripening. As a result, the Vitamin-C content of fruits was significantly improved by bioregulators. The present findings obtained on above parameters are also supported by Bhowmick et al., 2011 who observed highest acidity $(0.257 \%)$ content in Himsagar mango with $\mathrm{GA}_{3}$ application at $40 \mathrm{ppm}$. Similar observation on the effect of $\mathrm{GA}_{3}$ on acidity content in mango fruit was also made by other mango researchers Sharma et al., 1990 and Haidry et al., 1997. Increase in acidity level in fruits treated with $\mathrm{GA}_{3}$ may be due to the effect of GA on delaying maturity (Eman et al., 2007). 


\section{Total sugars}

The total sugars contents as influenced by bioregulators in cv. Ratol have been depicted in Table 3. The pooled values of total sugars were also affected due to foliar application of bio-regulators in the same way as was observed in 2011-12 and 2012-13. Pooled data revealed that foliar application of $50 \mathrm{ppm} \mathrm{GA}_{3}$ $(23.39 \%)$ had resulted in maximum increase in total sugars among all the treatments followed by $50 \mathrm{ppm} \mathrm{GA} 3(21.03 \%)$. However, the control fruits were found to have lowest level of total sugar $(12.47 \%)$. A maximum increase of $10.92 \%$ in total sugars was registered with $50 \mathrm{ppm} \mathrm{GA}_{3}$ in comparison with control. Furthermore, a maximum increase of $87.57 \%$ in total sugars was found over control with $50 \mathrm{ppm} \mathrm{GA}_{3}$ followed by $68.64 \%$ increase in total sugars over control with $25 \mathrm{ppm} \mathrm{GA}_{3}$.

The promotive effects of GA3 on total sugars have also been reported by other mango researchers (Shrivastava and Jain, 2006 and Haidry et al., 1997). The increase in the level of total sugars due to $\mathrm{GA}_{3}$ application in the present study might be due to involvement of PGRs in the breakdown of organic acids into sugars at the time of fruit ripening. Further, plant bio-regulators might assist the translocation of sugars from vegetative parts to developing fruits. Gibberellin is known to play a crucial role in the sugar metabolism of plants (Krishnamoorthy, 1993). Gibberellins actively participate in the hydrolysis of sucrose and starch. They promote the activity of enzyme invertase which catalyses the hydrolysis of sucrose, thereby yielding glucose and fructose. Further, GA is well known to delay senescence and fruit maturity. As a result, the level of acidity in $\mathrm{GA}_{3}$ treated fruits might have increased.

\section{Storage-life}

Storage life of Ratol mango was affected significantly by the application of bioregulators. Data recorded on above traits have been displayed in Table 4 . The pooled data of storage life was also found to be maximum (12.16 days) with $50 \mathrm{ppm} \mathrm{GA} 3$ followed by 25 ppm $\mathrm{GA}_{3}$ (9.75 days), while the minimum storage life of Ratol mango was registered with control (5.22 days). Data further revealed that a maximum increase of 6.94 days in storage life was recorded with $50 \mathrm{ppm} \mathrm{GA}$ as compared to control. Foliar application of 50 ppm $\mathrm{GA}_{3}$ also registered a maximum increase of $132.95 \%$ in storage life over control followed by $86.78 \%$ increase in storage life over control with 25 ppm GA $\mathrm{G}_{3}$.

Table.1 Effect of plant bio-regulators on Total soluble solids content in Ratol mango during 2011-12 and 2012-13

\begin{tabular}{|c|c|c|c|c|c|}
\hline \multirow[b]{2}{*}{ Treatments } & \multicolumn{3}{|c|}{ TSS $\left({ }^{\circ}\right.$ Brix $)$} & \multirow{2}{*}{$\begin{array}{l}\text { Improvement in } \\
\text { TSS over control }\end{array}$} & \multirow{2}{*}{$\begin{array}{c}\text { Percent increase (+) } \\
\text { or decrease(-) in TSS } \\
\text { over control }\end{array}$} \\
\hline & 2011-12 & 2012-13 & Pooled & & \\
\hline Control (Water spray) & 18.43 & 19.20 & 18.82 & - & - \\
\hline GA3 (25 ppm) & 20.50 & 20.80 & 20.65 & (+) 1.83 & (+) 09.72 \\
\hline GA3 (50 ppm) & 21.80 & 21.90 & 21.85 & (+) 3.03 & (+) 16.10 \\
\hline NAA $(25$ ppm) & 23.64 & 23.80 & 23.72 & (+) 4.90 & (+) 26.04 \\
\hline NAA $(50 \mathrm{ppm})$ & 24.18 & 24.70 & 24.44 & (+) 5.62 & (+) 29.86 \\
\hline Daminozide (50 ppm) & 22.30 & 22.50 & 22.40 & (+) 3.58 & (+) 19.02 \\
\hline Daminozide (100 ppm) & 23.10 & 23.40 & 23.25 & (+) 4.43 & (+) 23.54 \\
\hline Mean & 21.99 & 22.33 & 22.16 & (+) 3.57 & (+) 20.71 \\
\hline LSD $(\mathrm{P}<0.05 \%)$ & 0.960 & 0.971 & 0.767 & - & - \\
\hline $\operatorname{SEm} \pm$ & 0.312 & 0.315 & 0.222 & - & - \\
\hline
\end{tabular}


Table.2 Effect of plant bio-regulators on fruit titratable acidity in Ratol mango during 2011-12 and 2012-13

\begin{tabular}{|l|c|c|c|c|c|}
\hline \multirow{2}{*}{ Treatments } & \multicolumn{3}{|c|}{ Titratable acidity (\%) } & $\begin{array}{c}\text { Improvement in } \\
\text { titratable acidity } \\
\text { over control }\end{array}$ & $\begin{array}{c}\text { \% increase (+) or } \\
\text { decrease(-) in titratable } \\
\text { acidity over control }\end{array}$ \\
\hline Control (Water spray) & $2011-12$ & $2012-13$ & Pooled & - & - \\
\hline GA3 (25 ppm) & 0.09 & 0.10 & 0.09 & $(+) 0.07$ & $(+) 77.78$ \\
\hline GA3 (50 ppm) & 0.15 & 0.17 & 0.16 & $(+) 0.09$ & $(+) 100.00$ \\
\hline NAA (25 ppm) & 0.17 & 0.18 & 0.18 & $(+) 0.02$ & $(+) 22.22$ \\
\hline NAA (50 p pm) & 0.11 & 0.11 & 0.11 & $(+) 0.04$ & $(+) 44.44$ \\
\hline Daminozide (50 ppm) & 0.13 & 0.12 & 0.13 & $(+) 0.05$ & $(+) 65.55$ \\
\hline Daminozide (100 ppm) & 0.13 & 0.14 & 0.14 & $(+) 0.06$ & $(+) 61.11$ \\
\hline Mean & 0.15 & 0.16 & 0.15 & $(+) 0.05$ & - \\
\hline LSD (P< $\mathbf{0 . 0 5 \% )}$ & 0.13 & 0.14 & 0.135 & - & - \\
\hline SEm \pm & 0.010 & 0.015 & 0.010 & & -
\end{tabular}

Table.3 Effect of plant bio-regulators on total sugars content in Ratol mango during 2011-12 and 2012-13

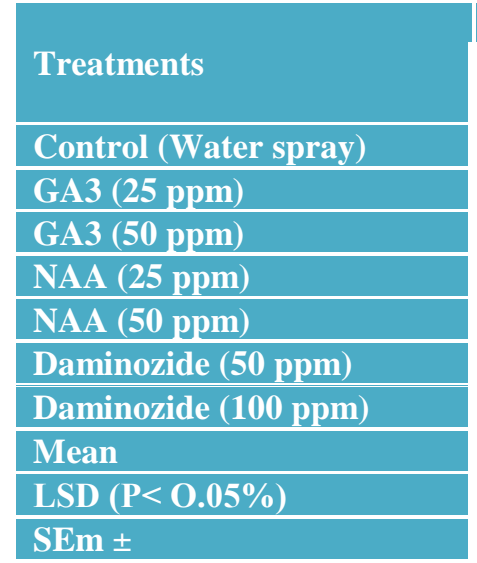

\begin{tabular}{|c|c|c|}
\hline \multicolumn{3}{|c|}{ Total sugars $(\%)$} \\
\hline $2011-12$ & $2012-13$ & Pooled \\
\hline 12.30 & 12.63 & 12.47 \\
\hline 19.77 & 22.30 & 21.03 \\
\hline 22.17 & 24.61 & 23.39 \\
\hline 19.36 & 20.36 & 19.86 \\
\hline 16.43 & 18.30 & 17.37 \\
\hline 18.37 & 17.66 & 18.01 \\
\hline 19.43 & 19.50 & 19.47 \\
\hline 18.26 & 19.34 & 18.80 \\
\hline 0.936 & 0.907 & 0.732 \\
\hline 0.304 & 0.294 & 0.212 \\
\hline
\end{tabular}

\begin{tabular}{|c|c|}
\hline $\begin{array}{l}\text { Improvement in } \\
\text { total sugars } \\
\text { over control }\end{array}$ & $\begin{array}{l}\% \text { increase }(+) \text { or } \\
\text { decrease }(-) \text { in total } \\
\text { sugars over control }\end{array}$ \\
\hline - & - \\
\hline (+) 8.56 & (+) 68.64 \\
\hline (+) 10.92 & (+) 87.57 \\
\hline (+) 7.39 & (+) 59.26 \\
\hline (+) 4.90 & (+) 39.29 \\
\hline (+) 5.54 & (+) 44.43 \\
\hline (+) 7.00 & (+) 56.13 \\
\hline (+) 7.38 & (+) 59.22 \\
\hline- & - \\
\hline- & - \\
\hline
\end{tabular}

Table.4 Effect of plant bio-regulators on storage life in Ratol mango during 2011-12 and 2012-13

\begin{tabular}{|c|c|c|c|c|c|}
\hline \multirow[b]{2}{*}{ Treatments } & \multicolumn{3}{|c|}{ Storage life (days) } & \multirow{2}{*}{$\begin{array}{l}\text { Improvement in } \\
\text { days of storage life } \\
\text { over control }\end{array}$} & \multirow{2}{*}{$\begin{array}{l}\% \text { increase }(+) \text { or } \\
\text { decrease }(-) \text { in storage } \\
\text { life over control }\end{array}$} \\
\hline & 2011-12 & $2012-13$ & Pooled & & \\
\hline Control (Water spray) & 5.10 & 5.33 & 5.22 & - & - \\
\hline GA3 (25 ppm) & 9.17 & 10.33 & 9.75 & (+) 4.53 & (+) 86.78 \\
\hline GA3 (50 ppm) & 11.66 & 12.66 & 12.16 & (+) 6.94 & (+) 132.95 \\
\hline NAA (25 ppm) & 6.20 & 6.80 & 6.50 & (+) 1.28 & (+) 24.52 \\
\hline NAA (50 ppm) & 7.66 & 8.10 & 7.88 & (+) 2.66 & (+) 50.96 \\
\hline Daminozide (50 ppm) & 7.33 & 8.33 & 7.83 & (+) 2.61 & (+) 50.00 \\
\hline Daminozide (100 ppm) & 9.55 & 9.67 & 9.61 & (+) 4.39 & (+) 84.10 \\
\hline Mean & 8.10 & 8.75 & 8.42 & (+) 3.73 & (+) 71.55 \\
\hline LSD $(\mathrm{P}<0.05 \%)$ & 0.607 & 0.601 & 0.480 & - & - \\
\hline SEm \pm & 0.197 & 0.195 & 0.139 & - & - \\
\hline
\end{tabular}


Table.5 Effect of plant bio-regulators on decay loss in Ratol mango during 2011-12 and 2012-13

\begin{tabular}{|c|c|c|c|c|c|}
\hline \multirow[b]{2}{*}{ Treatment } & \multicolumn{3}{|c|}{ Decay loss (\%) } & \multirow{2}{*}{$\begin{array}{l}\text { Improvement } \\
\text { in decay loss } \\
\text { over control }\end{array}$} & \multirow{2}{*}{$\begin{array}{c}\% \text { increase (+) or } \\
\text { decrease }(-) \text { in Decay } \\
\text { loss over control }\end{array}$} \\
\hline & 2011-12 & $2012-13$ & Pooled & & \\
\hline Control (Water spray) & 51.67 & 54.45 & 53.06 & - & - \\
\hline GA3 (25 ppm) & 11.20 & 12.50 & 11.85 & (-) 41.21 & (-) 77.67 \\
\hline GA3 (50 ppm) & 7.76 & 8.30 & 8.03 & (-) 45.03 & (-) 84.87 \\
\hline NAA (25 ppm) & 15.69 & 16.83 & 16.26 & (-) 36.80 & $(-) 69.36$ \\
\hline NAA (50 ppm) & 18.50 & 19.26 & 18.88 & (-) 34.18 & (-) 64.42 \\
\hline Daminozide (50 ppm) & 17.43 & 18.76 & 18.10 & (-) 34.96 & (-) 65.89 \\
\hline Daminozide (100 ppm) & 20.83 & 21.89 & 21.36 & (-) 31.70 & (-) 59.74 \\
\hline Mean & 20.44 & 21.71 & 21.08 & (-) 26.74 & $(-) 7.33$ \\
\hline LSD $(P<0.05 \%)$ & 1.203 & 0.768 & 0.801 & - & - \\
\hline $\mathrm{SEm} \pm$ & 0.390 & 0.249 & 0.232 & - & - \\
\hline
\end{tabular}

Table.6 Effect of plant bio-regulators on organolepic quality in Ratol mango during 2011-12 and 2012-13

\begin{tabular}{|c|c|c|c|c|c|}
\hline \multirow[b]{2}{*}{ Treatment } & \multicolumn{3}{|c|}{ Organoleptic quality } & \multirow{2}{*}{$\begin{array}{l}\text { Improvement } \\
\text { in organoleptic } \\
\text { quality over } \\
\text { control }\end{array}$} & \multirow{2}{*}{$\begin{array}{c}\% \text { increase }(+) \text { or } \\
\text { decrease }(-) \text { in } \\
\text { organoleptic quality } \\
\text { over control }\end{array}$} \\
\hline & 2011-12 & $2012-13$ & Pooled & & \\
\hline Control (Water spray) & 1 & 1.33 & 1.16 & - & - \\
\hline GA3 (25 ppm) & 3.67 & 3.67 & 3.67 & (+) 2.51 & (+) 216.37 \\
\hline GA3 (50 ppm) & 4.33 & 4.67 & 4.50 & (+) 3.34 & (+) 287.93 \\
\hline NAA (25 ppm) & 2 & 2.33 & 2.17 & (+) 1.01 & (+) 87.06 \\
\hline NAA (50 ppm) & 3 & 3.33 & 3.17 & (+) 2.01 & (+) 173.27 \\
\hline Daminozide (50 ppm) & 3.33 & 3.67 & 3.50 & (+) 2.34 & (+) 201.72 \\
\hline Daminozide (100 ppm) & 4 & 4 & 4 & (+) 2.84 & (+) 244.82 \\
\hline Mean & 3.047 & 3.280 & 3.167 & (+) 2.34 & (+) 201.86 \\
\hline LSD $(P<0.05 \%)$ & 1.350 & 1.099 & 0.074 & - & - \\
\hline $\operatorname{SEm} \pm$ & 0.433 & 0.353 & 0.024 & - & - \\
\hline
\end{tabular}

Similar response of $\mathrm{GA}_{3}$ on shelf-life of mango fruits was observed by Islam et al., 2013 and Singh et al., (2008) who had reported that $\mathrm{GA}_{3}$ enhanced the storage life of mango up to 6 days under ambient temperature between $36 \pm 2$ and $40 \pm 3{ }^{\circ} \mathrm{C}$. The promotive effect of $\mathrm{GA}_{3}$ on extending shelflife of mango fruits may be due to the fact that GA is well known for maintaining chlorophyll and delaying senescence (Eman $e t$ $a l$. , 2007). This is further supported by the fact that $\mathrm{GA}_{3}$ application decreases the tissue permeability and thereby reduced the rate of water loss leading to delayed fruit ripening (Nirupama et al., 2010).

\section{Decay loss}

Foliar application of bio-regulators significantly affected decay loss in Ratol mango during both the years of investigation. Data on decay loss have been depicted in 
Table 5. Data revealed that the decay loss ranged from $8.03 \%\left(50 \mathrm{ppm} \mathrm{GA}_{3}\right)$ to $53.03 \%$ (control) during both years of the investigation. Significantly lowest decay loss of fruits was recorded with 50 ppm $\mathrm{GA}_{3}$ (7.76 $\%$ and $8.30 \%$ ) followed by 25 ppm $\mathrm{GA}_{3}$ (11.20\% and $12.50 \%$ ), while maximum with control $(51.67 \%$ and $54.45 \%)$ during both the years of investigation, respectively. A maximum reduction of $45.03 \%$ in decay loss was registered with $50 \mathrm{ppm} \mathrm{GA}_{3}$ in comparison with control. Data also revealed a maximum reduction of $84.87 \%$ in decay loss over control.

Similar promotive effect of $\mathrm{GA}_{3}$ in reducing decay loss in mango fruit was also observed by Kumar et al., (1993) who found that preharvest sprays of $\mathrm{GA}_{3}$ (50 or 75 ppm.) brought forward fruit maturity by 8-11 days and significantly reduced decay loss during storage.

\section{Organoleptic quality}

The acceptability of fruit quality in the current study was judged on the basis of colour, aroma, flavour, taste, texture and firmness on 5 points hedonic scale by the panel of 4 judges. The perusal of data indicated the significant response of bio-regulators on organoleptic quality of Ratol mango (Table 6). The pooled data of organoleptic quality was also affected significantly due to foliar application of bio-regulators. The pooled data revealed significantly maximum organoleptic score with $50 \mathrm{ppm} \mathrm{GA}_{3}$ (4.50 score value).

Further, a maximum increase of $287.93 \%$ in organoleptic quality over control) was observed with $50 \mathrm{ppm} \mathrm{GA}_{3}$ increase in organoleptic quality over control with 100 ppm Daminozide. Foliar application of 50 ppm $\mathrm{GA}_{3}$ resulted in maximum improvement in organoleptic quality of Ratol mango during both the years of investigation.
The application of exogenous bio-regulators can bring changes in chemical properties of fruits which can improve the organoleptic quality. These findings are in accordance with the findings of Chahal and Bal (2004) who also reported higher organoleptic ratings in mango fruits when treated with $\mathrm{GA}_{3}$; Rubi et al., (2003) who also recorded high consumer acceptability (6.91) with 100 ppm GA . The promotive effect of $\mathrm{GA}_{3}$ on Organoleptic quality was also reported by Arora et al., (2014) who recorded maximum palatability rating of mango fruits with $50 \mathrm{ppm} \mathrm{GA}_{3}$ application. Conclusively, NAA @ 50 ppm treatment induced maximum TSS while $\mathrm{GA}_{3}$ @ 50 ppm induced maximum titratable acidity, total sugar, storage life and reduction in decay loss. GA 3 @ 50 ppm also enhanced organoleptic quality of fruits. Therefore, both NAA@ 50 ppm and $\mathrm{GA}_{3} @ 50$ ppm can be utilized for enhancing the chemical parameters storage life and improving the organoleptic quality of Ratol mango.

\section{Acknowledgement}

The authors acknowledge the Institute fellowship from Rajiv Gandhi National Fellowship and infrastructural facilities received from the Department of Horticulture, Sardar Vallabhbhai Patel University of Agriculture and Technology, Meerut, U.P. Special thanks to respected Dr. Satya Prakash, Professor (Department of Horticulture, SVPUAT, Meerut); Dr. Virendra Kumar (Department of Pathology, CSAUAT) and Dr. Anil Kumar (Department of Horticulture, SHUATS, Allahabad) for critically going through the manuscript and giving suggestions.

\section{References}

Anila, R. and Radha, T., 2003. Studies on fruit drop in mango varieties. $J$. Tropical Agric., 41: 30-32. 
Anonymous (2017). NHB, Gurgaon, Haryana.

Arora, R. and Singh, S. (2014). Effect of growth regulators on quality (zizyphus mauritiana lamk) of ber cv. Umran. Agric. Sci. Digest., 34(2): 102-106.

Bairangi, P. (2013). Effect of different chemicals on yield, quality and shelflife of different varieties of mango, M.Sc. Thesis, Department of Horticulture, Bangladesh Agricultural University, Bangladesh.

Baker, D.A. (1985). Regulation of phloem loading. Monograph 12: 163-176.

Bhowmick, N. and Banik, B.C. (2011). Influence of pre-harvest foliar application of growth regulators and micronutrients on mango cv. Himsagar. Indian J. Hort. 68(1): 103-107

Chahal, S. and Bal, J.S., (2004). Quality of GA, NAA and wax treated ber (Zizyphus mauritiana Lamk.) fruits after storing them in cold storage for different duration. Haryana J Hort Sci. 33: $240-42$

Eman, A.A.A., Omayma, M.M.M.A. and Ismail, M.M. (2007). $\mathrm{GA}_{3}$ and zinc sprays for improving yield and fruit quality of Washington Navel orange trees grown under sandy soil conditions. J. Agr. Biol. Sci. 3: 498-503.

Haidry, G.A., Jala-Ud-Din, B. and Ghaffoor, A. (1997). Effect of naphthalene acetic acid on the fruit drop, yield and quality of mango (Mangifera indica L.) cultivar 'Langra'. Sci. Khyber. 10: 13-20.

Islam, M.K., Sarkar, M.A.R., Yeasmin, S. and Uddin, M.H. (2013). Post-harvest quality of mango (Mangifera indica L.) fruit affected by different levels of gibberellic acid during storage. Malaysian J. Analytical Sci. 7(3): 499509.

Khader, S.E.S.A. (1992). Effect of pre-harvest application of $\mathrm{GA}_{3}$ on post-harvest behaviour of mango fruits. Scientia Hort. 47(3-4): 317-312.
Krishnamoorthy, H.N. (1993). Physiology of plant growth and development. Atma Ram and Sons Publishers, New Delhi, India.

Kumar, P. and Singh, S. (1993). Effect of $\mathrm{GA}_{3}$ and Ethrel on ripening and quality of mango cv. Amrapali. Hort. J. 6(1): 19-23.

Kumar, R. and Nagpal, R. (1996). Effect of post-harvest treatment on the storage behaviour of mango cv. Dasheheri. Haryana J. Hort. Sci. 25: 101-108.

Nirupama P., Neeta B.G. and Rao, T.V.R. (2010). Effect of post-harvest treatments on physio-chemical Characteristics and shelf-life tomato fruits during storage. AmericanEurasian J. Agri. \& Environ. Sci., 9(5): 470-479.

Nkansah, G.O., Ofosu-Anim, J. and Mawuli, A. (2012). Gibberellic acid and naphthalene acetic acid affect fruit retention, yield and quality of Keitt mangoes in the coastal Savanna ecological zone of Ghana. American J. Plant Physiol., 7(6): 243-351.

Osama, H.M. El Gammal, Amro, S.M.S. and Saber, M.M.B. (2015) Effect of growth regulator, antioxidant and application date on fruiting and fruit quality of mango trees cv. Keitt. J. Agri. and Veteri. Sci. 8(1): 87-95.

Panse, V.G. and Sukhatme, P.V. (1985). Statistical method for the agricultural workers $2^{\text {nd }}$ edn. I.C.A.R. New Delhi.

Rubi, R. and Brahmachari, V.S. (2003). Effect of foliar application of chemical on quality characters of mango during storage. Progressive Hort. 35(2): 216218.

Sharma, T.R.., Niar, P.K. and Nema, M.K. (1990). Effect of foliar spray of urea, $\mathrm{KNO}_{3}$ and NAA on fruiting behaviour of mango cv. 'Langra'. Orissa J. Hort. 18: $42-47$. 
Shrivastava, D.K. and Jain, D.K. (2006). Effect of urea and $\mathrm{GA}_{3}$ on physiochemical properties of mango cv. 'Langra' during year. Karnataka J. Agri. Sci. 19: 754-756.

Singh, A., Kumar, J. and Kumar, P. (2008). Effects of plant growth regulators and sucrose on post-harvest physiology, membrane stability and vase life of cut spikes of gladiolus. Plant Growth

Singh, R.N. (1958). Studies in the differentiation and development of fruit bud in mango. II Morphological and histological changes. Hort. Adv., 2: 37. Vejendla, V., Maity, P.K. and Bank, B.C. (2008). Effect of chemicals and growth regulators on fruit retention, yield and quality of mango cv. Amrapali. J. Crop \& Weed, 4(2): 45-46. Regulation. 55: 221-229.

\section{How to cite this article:}

Dharmendra Kumar Gautam, Anil Kumar, Virendra Kumar, Mahesh Kumar and Satya Prakash. 2018. Effect of Bio-Regulators on Improvement in Chemical Traits, Storage Life and Organoleptic Quality of Ratol Mango. Int.J.Curr.Microbiol.App.Sci. 7(08): 3802-3810. doi: https://doi.org/10.20546/ijcmas.2018.708.388 